\title{
The relationship between occupational culture dimensions and reward preferences: A structural equation modelling approach
}

\begin{tabular}{|c|c|}
\hline \multicolumn{2}{|c|}{$\begin{array}{l}\text { Authors: } \\
\text { Mark Bussin }{ }^{1} \\
\text { Michelle Nicholls }^{1} \\
\text { Ronel Nienaber }^{1}\end{array}$} \\
\hline \multicolumn{2}{|c|}{$\begin{array}{l}\text { Affiliations: } \\
\text { 'Department of Industrial } \\
\text { Psychology and People } \\
\text { Management, University of } \\
\text { Johannesburg, South Africa }\end{array}$} \\
\hline \multicolumn{2}{|c|}{$\begin{array}{l}\text { Corresponding author: } \\
\text { Mark Bussin, } \\
\text { drbussin@mweb.co.za }\end{array}$} \\
\hline \multicolumn{2}{|c|}{$\begin{array}{l}\text { Dates: } \\
\text { Received: } 15 \text { July } 2015 \\
\text { Accepted: } 01 \text { Feb. } 2016 \\
\text { Published: } 17 \text { June } 2016\end{array}$} \\
\hline \multicolumn{2}{|c|}{$\begin{array}{l}\text { How to cite this article: } \\
\text { Bussin, M., Nicholls, M., \& } \\
\text { Nienaber, R. (2016). The } \\
\text { relationship between } \\
\text { occupational culture } \\
\text { dimensions and reward } \\
\text { preferences: A structural } \\
\text { equation modelling } \\
\text { approach. SA Journal of } \\
\text { Human Resource } \\
\text { Management/SA Tydskrif vir } \\
\text { Menslikehulpbronbestuur, } \\
\text { 14(1), a737. http://dx.doi. } \\
\text { org/10.4102/sajhrm. } \\
\text { v14i1.737 }\end{array}$} \\
\hline \multicolumn{2}{|c|}{$\begin{array}{l}\text { Copyright: } \\
\text { (c) 2016. The Authors. } \\
\text { Licensee: AOSIS. This work } \\
\text { is licensed under the } \\
\text { Creative Commons } \\
\text { Attribution License. }\end{array}$} \\
\hline \multicolumn{2}{|l|}{ Read online: } \\
\hline 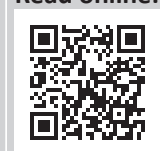 & $\begin{array}{l}\text { Scan this QR } \\
\text { code with your } \\
\text { smart phone or } \\
\text { mobile device } \\
\text { to read online. }\end{array}$ \\
\hline
\end{tabular}

Orientation: Reward has links to employee attraction and retention and as such has a role to play in managing talent. However, despite a range of research, there is still lack of clarity on employee preferences relating to reward.

Research purpose: The purpose of the research was to recommend and appraise a theoretical model of the relationship between occupational culture dimensions and reward preferences of specific occupational groups in the South African context.

Motivation for the study: The motivation for this study was to address the gap that exists with reward preferences and occupational culture with a view to identifying and gaining insight into individual preferences.

Research design, approach and method: A structural equation modelling approach was adopted in exploring the proposed relationships. A South African Information, Communication, and Technology (ICT) organisation served as the population, and a web-based survey assisted in gathering study data $(n=1362)$.

Main findings: The findings provided support for the relationship between occupational culture dimensions and certain reward preferences. In particular, statistically significant results were obtained with the inclusion of the Environment, Team, and Time occupational culture dimensions as independent variables.

Practical implications and value-add: The study provides workable input to organisations and reward professionals in the design of their reward strategies and programmes.

\section{Introduction}

\section{Key focus of the study and background}

Employee turnover remains a concern for employers (Silverstone, 2009). Organisations continue to face the challenge of retaining the key skills and competencies required to achieve organisational objectives, particularly so in a very demanding economic climate and competitive talent market (Moore \& Bussin, 2012; Munsamy \& Venter, 2009; Nzukuma \& Bussin, 2011). Bhattacharya and Mukherjee (2009) highlight the association between employee retention and reward. Employee reward is concerned with the reward of individuals as aligned to the value that they add to the organisation (Armstrong, 2002). Despite the introduction of a total reward approach (WorldatWork, 2008), effective reward remains a challenge for organisations.

\section{Trends from the research}

Research has considered reward preferences from a range of standpoints in an attempt to better comprehend individual preferences. This has included consideration of the influence of demographic factors such as race, gender, age and marital status (Moore \& Bussin, 2012; Nienaber, Bussin \& Henn, 2011; Schlechter, Thompson \& Bussin, 2015; Snelgar, Renard \& Venter, 2013), personality type (Nienaber et al., 2011; Vandenberghe, St-Onge \& Robineau, 2008), generational theory (Bunton \& Brewer, 2012; Bussin \& Van Rooy, 2014; Smit, Stanz \& Bussin, 2015; Snelgar et al., 2013), industry (Bussin \& Toerien, 2015) and the influence of national culture on reward preferences (Herkenhoff, 2000; Newman \& Nollen, 1996; Schuler \& Rogocsky, 1998; Westerman, Beekun, Daly \& Vanka, 2009), led primarily by Hofstede's (1980) research. Despite these studies,

Note: This article is partially based on Michelle Nicholls' thesis of the degree of Doctor of Philosophiae in Human Resource Management at the Department of Industrial and People Management, University of Johannesburg, South Africa, with supervisor Prof. M. Bussin and co-supervisor Dr R. Nienaber, received October 2012, available here: http://ujdigispace.uj.ac.za/bitstream/handle/10210/8356/Nicholls. pdf?sequence=1 
further clarity is still required on how organisations should devise appropriate reward strategies, especially when dealing with non-financial rewards (Armstrong \& Stephens, 2005; Schlechter et al., 2015).

While the impact of national culture on reward preferences has been researched (Herkenhoff, 2000; Hofstede, 1980; Westerman et al., 2009), occupational culture offers a further level of culture, which impacts on employee behaviour informed by membership to an occupational group (Lachman, Nedd \& Hinings, 1995). As with national culture, occupational culture too may impact on employee behaviour in terms of reward preferences; however, this has not been empirically tested and explored in the literature as yet.

\section{Research objectives}

The primary purpose of this study was to research reward preferences from an occupational culture perspective within the South African context. In line with this purpose, the main objective of the research was to propose and evaluate a theoretical model of the relationship between occupational culture dimensions and employee reward preferences. The core research problem relates to a gap in empirical research of the effect occupational culture has on reward preferences.

\section{The potential value-add of the study}

By assessing the extent to which occupational groups prefer the different types of reward offered in the workplace, organisations will be more informed and enabled to leverage benefit from the structuring of the different reward elements in accordance with these preferences, thereby aiding retention efforts. In addition, consideration of occupational groups from a time orientation perspective in particular may guide organisations to structure incentive plans in such a manner that the preference for short- or long-term incentives can be optimised to achieve the greatest return for this investment. Organisations too can consider the findings in the application of the principles relating to pay allocation and pay orientation.

\section{What will follow}

The next section is a review of the literature, outlining research on the main constructs and integrating it with this research. This is followed by a description of the research design, findings, results and discussion.

\section{Synthesis and critical evaluation of the literature and hypotheses Occupational culture theory}

While organisations display their own culture, further cultures (known as subcultures) are evident within the larger organisational system. Subcultures form along different lines, and occupation is proposed as one of the most pronounced differentiators in the organisation context (Trice, 1993). Culture pertains to shared values, beliefs and ideas.
Occupational culture theory holds that shared values, beliefs, ideas and orientations are based on membership in a specific profession or occupation group (Ames, Duke, Moore \& Cunradi, 2009; Sheer \& Chen, 2003; Trice, 1993). From an organisational perspective, values, beliefs and orientations influence the behaviour of employees (Herkenhoff, 2004). By nature, shared values and beliefs may therefore impact the behaviour of occupational groups. This impact may be evident in aspects such as reward preferences. Viitanen (2000) highlights that contributing to the formation of occupational cultures are the rights, privileges and obligations that employees have, based on their occupational group. Characteristics of occupational cultures include factors such as unique training and development, particular duties, control over certain functions and tasks, possessing specific competencies, knowledge and skills and obtaining specific qualifications and membership in professional and occupational bodies and associations (O'Hara-Devereaux \& Johansen, 1994; Schein, 2004; Trice, 1993).

\section{Dimensions of occupational culture}

Hofstede's (1980) national culture dimensions assist in the study of occupational culture (Ulijn, Nagel \& Liang, 2001). Herkenhoff (2009) concurs and has highlighted that by measuring occupational culture against relevant occupational culture dimensions, it is possible for researchers to assess relative differences across occupational groups. Herkenhoff (2009) proposed five occupational culture dimensions, namely Power, Risk, Gender, Time and Team.

\section{Power}

The Power occupational culture dimension considers the extent to which power differences are accepted and addressed within the occupation (Herkenhoff, 2009). From this premise, a high score on the Power dimension highlights that an individual is more likely to accept power differences. From a national culture perspective, this is aligned to the Power Distance national culture dimension (Hofstede, 1991; Punnett \& Ricks, 1997) and deals with the extent to which inequality in society is accepted. High Power Distance national cultures would typically display the following characteristics: bureaucratic, hierarchical structures; defined and accepted order and ranking; decision making that is centralised; as well as authoritarian-based leadership (Lee \& Carter, 2005; Mead, 1990; Punnett \& Ricks, 1997). Erez (1997) highlights that is this is evident in reward systems too where pay differences based on an employee's grade or level are readily accepted (Erez, 1997). Conversely, aspects such as extensive consultation, promotion of equal rights and the possibility to change status and ranking are characteristic of low Power Distance cultures. Within the organisation context, this is evident in flatter structures, smaller pay differentials and a leadership style that is more democratically based (Hofstede, 1995; Punnett \& Ricks, 1997). Given the empirical links between national culture and reward, the following directional hypotheses are proposed with regards to the 
relationship between the occupational culture dimension of Power and employee reward preferences:

- Hypotheses $1\left(\mathbf{H}_{1}\right)$ : A positive relationship is predicted between Power and Job-level-based benefits.

- Hypotheses $2\left(\mathbf{H}_{2}\right)$ : A positive relationship is predicted between Power and Performance and recognition.

- Hypotheses $3\left(\mathbf{H}_{3}\right)$ : A positive relationship is predicted between Power and Career and development.

\section{Risk}

The Risk occupational culture dimension gives consideration to the degree to which taking risks is accepted and encouraged among members of the occupational group. In this instance, for occupational groups that display a low score on the Risk dimension, members try to avoid risk and uncertainty. As highlighted by Herkenhoff (2009), this is typically evident in attempts to cater for eventualities through documenting procedures, roles and processes. Occupationally, reduced risk and uncertainty would be associated with predictable and routine jobs (for example, payroll clerk) and this would be evident through a low score on the Risk dimension. Conversely, jobs associated with risk and chance taking (e.g. fire fighters) show a high score on this dimension. From a national culture perspective, Risk is aligned to Uncertainty Avoidance. This pertains to the manner in which uncertainty is dealt with and the tendency to either promote uncertainty or seek surety. This is likened to low and high uncertainty avoidance cultures, respectively (Hofstede, 1980). From a work perspective, high uncertainty avoidance is evident in a need for job security, mapped career paths, retirement plans as well as clear goals, roles and responsibilities. Low uncertainty avoidance is witnessed through risk taking, more informality in roles and processes and quick decision making (Hofstede, 1995; Lee \& Carter, 2005; Mead, 1990; Punnett \& Ricks, 1997). Given the literature presentations, the following directional hypotheses are formulated regarding the relationship between the occupational culture dimension of Risk and employee reward preferences:

- Hypotheses $4\left(\mathbf{H}_{4}\right)$ : A negative relationship is predicted between Risk and Guaranteed package.

- Hypotheses $5\left(\mathrm{H}_{5}\right)$ : A negative relationship is predicted between Risk and Pension.

- Hypotheses $6\left(\mathbf{H}_{6}\right)$ : A negative relationship is predicted between Risk and Short-term incentives.

- Hypotheses $7\left(\mathrm{H}_{7}\right)$ : A negative relationship is predicted between Risk and Job security.

\section{Gender}

The Gender occupational culture dimension, which incorporates the Service, Machismo, and Environment dimensions, deals with the extent to which gender-based role differentiation is experienced and promoted within the occupation (Herkenhoff, 2009). Service relates to the degree to which the occupation involves providing assistance or service to others. Machismo is associated typically with male-dominated occupations, while Environment considers the extent to which the occupation places value on the workplace environment (Herkenhoff, 2009).
In the present study, the Service and Environment dimensions are considered. From a national culture perspective, the Gender dimension can be associated with the Masculinity-Femininity dimension (Hofstede, 1980). Masculinity is associated with the degree to which traditional male behaviour or values (for example, assertiveness and ambition) are promoted in the community. Workwise, this plays out in differentiated work roles and an achievement orientation (Mead, 1990; Punnett \& Ricks, 1997). More feminine cultures are typically more fluid in their gender roles and emphasis is placed on traditional feminine values, such as orientation focus on relationships. Workwise, it translates into a focus on work-life balance, a pleasant working environment and social welfare considerations (Hofstede, 1995; Lee \& Carter, 2005; Punnett \& Ricks, 1997). Given these national culture links, the following directional hypotheses are formulated regarding the relationship between the Gender occupational culture dimensions of Environment and Service and employee reward preferences:

- Hypotheses $8\left(\mathrm{H}_{8}\right)$ : A positive relationship is predicted between Environment and Performance and recognition.

- Hypotheses $9\left(\mathbf{H}_{9}\right)$ : A positive relationship is predicted between Environment and Career and development.

- Hypotheses $\mathbf{1 0}\left(\mathrm{H}_{10}\right)$ : A positive relationship is predicted between Environment and Work hours.

- Hypotheses $\mathbf{1 1}\left(\mathrm{H}_{11}\right)$ : A positive relationship is predicted between Environment and Family-related benefits.

- Hypotheses $12\left(\mathrm{H}_{12}\right)$ : A positive relationship is predicted between Service and Work hours.

- Hypotheses $\mathbf{1 3}\left(\mathrm{H}_{13}\right)$ : A positive relationship is predicted between Service and Family-related benefits.

\section{Time}

Time refers to the degree to which the occupational group is long-term focused (Herkenhoff, 2009). Occupational groups that display a short-term orientation (that is a low score on the Time occupational culture dimension) display a preference for short-term results and feedback from a work and reward perspective, an example being a call centre agent with daily outbound call targets. Conversely, occupational groups that display a long-term orientation (a high score on the Time occupational culture dimension) place more emphasis on goals, rewards and objectives that are future based (Herkenhoff, 2009). From a national culture perspective, this aligns with Bond's (1988) Long-term orientation dimension. Based on the presented literature, the following directional hypotheses are formulated regarding the relationship between the occupational culture dimension of Time and employee reward preferences:

- Hypotheses $14\left(\mathrm{H}_{14}\right)$ : A positive relationship is predicted between Time and Pension.

- Hypotheses $\mathbf{1 5}\left(\mathrm{H}_{15}\right)$ : A negative relationship is predicted between Time and Short-term incentives.

\section{Team}

The Team occupational culture dimension can be likened to the Individualism-Collectivism national culture dimension, 
which considers the individual in relation to his or her national culture group (Hofstede, 1980; Trompenaars, 1993). Herkenhoff (2009) concurs that it relates to the extent to which personal needs and desires are primary to those of the collective. Occupationally, this relates to the promotion of the needs of the individual versus those of the group. A high score on the Team dimension is associated with collectivism, while a low score on the Team dimension is aligned to individualism. Workwise, the dimension has an influence on reward systems. This is apparent in the equity and equality pay allocation principles (Erez, 1997). Equity can be associated with Individualism while equality aligns to a team orientation, namely Collectivism. Effective reward in high individualist cultures focuses on practices that encourage and reward independent work and decision making, while in low individualist cultures, reward would be group based on group decision making and performance (Mead, 1990; Punnett \& Ricks, 1997). In low individualist cultures, it may be found that top performers share their monetary reward for goal attainment with the team (Trompenaars, 1993), thereby practically displaying the principle of Collectivism. The following directional hypotheses are formulated regarding the relationship between the occupational culture dimension of Team and employee reward preferences:

- Hypotheses $16\left(\mathrm{H}_{16}\right)$ : A positive relationship is predicted between Team and Team pay.

- Hypotheses $17\left(\mathrm{H}_{17}\right)$ : A positive relationship is predicted between Team and Team equal.

\section{Reward theory}

The international professional reward association, WorldatWork, advocates a total reward approach to employee reward. Total reward can be defined as the monetary and non-monetary return provided to employees in exchange for their time, talents, efforts, and results' (WorldatWork, 2007, p. 4). This approach considers the employee holistically in terms of personal and professional needs. In consideration with the range of employee needs, total reward encompasses rewards that are financially and non-financially based. Financial reward, for example, payand monetary-based incentives, speaks to the individual's financial needs. Non-financial reward encompasses aspects such as opportunities for learning and growth, career prospects and management, organisational values, performance and recognition, relationships at work, job security and work-life balance (Armstrong, 2002; Thompson \& McHugh, 2002; WorldatWork, 2008).

\section{Total reward frameworks}

The framework utilised in the study for total reward is indicated in Figure 1. The total reward framework incorporates financial rewards, non-financial rewards and benefits. Financial rewards incorporate two reward elements, namely Guaranteed package and short- and/or long-term incentives (Bussin, 2011). Guaranteed package is a primarily South African-based reward term and refers to basic pay in this

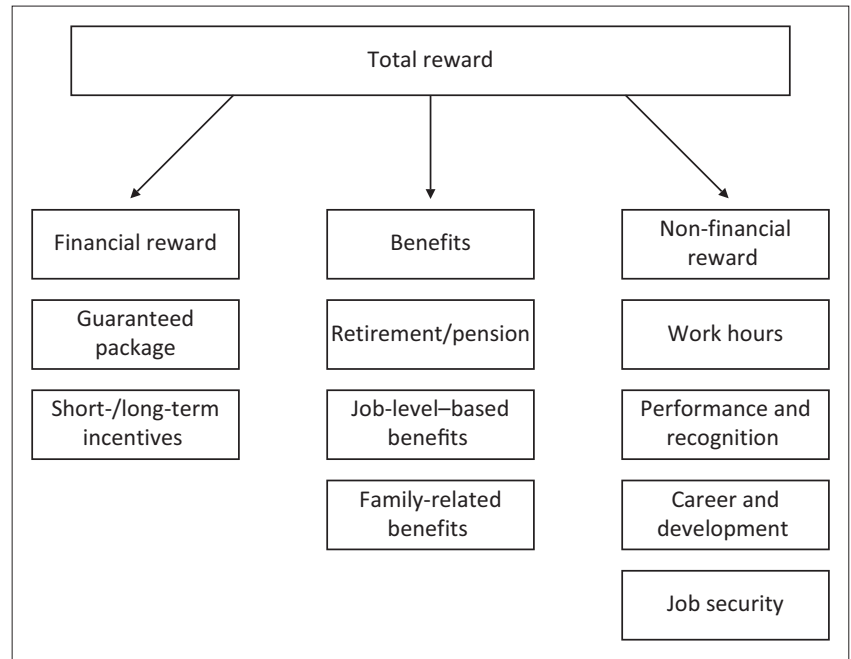

FIGURE 1: Total reward framework adopted in the study.

instance. As suggested by WorldatWork (2008), provision was included for the following non-financial reward elements, namely Work hours (representing work-life balance), Performance and recognition and Career and development opportunities. Job security is incorporated as a non-financial reward element, given the primarily intangible nature of this reward element. Benefits include Retirement or pension, Joblevel-based benefits and Family-related benefits as per Herkenhoff's (2000) national culture or pay study.

The study further considers pay orientation and pay allocation principles referred to as Team pay and Team equal, respectively.

\section{Research design, approach and method \\ Research approach}

The research design was exploratory and explanatory. The research was quantitative and a structural equation modelling (SEM) approach was selected in order to test the hypotheses and to explore the proposed relationships between the latent and observed research variables (Nye \& Drasgow, 2011).

\section{Research method}

Participants and sample: A South African Information, Communication, and Technology (ICT) organisation was selected for the study purpose considering its 20420 employees who are employed on a permanent basis. All employees up to and including first-line management who are South African nationals were considered. The population was divided into occupational groups and sorted according to employee reference numbers. Every tenth employee per occupational group was selected for the sample. Some occupational groups consisted of small representations (e.g. Accountants), and these groups were excluded. The final sample included the following occupational groups: Manager, Information Technology, Technician, Clerical or Admin and Sales. 
The output of the sampling was a study sample of 10581 . Data collection resulted in 1362 usable questionnaires, which represents a $12.9 \%$ response rate (the study organisation typically obtains a $10 \%$ response rate to surveys; the response rate was therefore aligned to the norm). Table 1 provides a profile of the respondents. All race groups participated in the study, with the bulk of respondents being white people $(48.3 \%)$, male gender $(70.1 \%)$ and from the 40 - to 49 -year age group (41.3\%). The Technician occupational group had the largest representation $(44.4 \%)$. The age, gender and occupational group distribution of respondents was representative of the target population. In terms of race, the white group was over-represented, and conversely, the African group was under-represented.

Measuring instrument: A web-based survey was utilised in the study. The first part of the survey related to biographical and demographic data collection. The second part, which made use of a five-point Likert-type rating scale, contained the independent and dependent variable measurement scales. The following descriptors were used: 1 = strongly disagree, 2 = disagree, 3 = neither disagree nor agree, $4=$ agree and $5=$ strongly agree.

\section{Biographical and demographic questionnaire}

The biographical and demographic questionnaire requested respondent information regarding age, race, gender and occupational group.

\section{Occupational culture questionnaire}

Background to the questionnaire: Herkenhoff's (2010) Professional Culture questionnaire (PC08) served as the basis for the design of the occupational culture questionnaire (PC10). The PC08 measured occupational culture differences based on the five national culture dimensions proposed by Hofstede (1980) and Bond (1988). There is paucity of occupational culture measurement tools available, and

\begin{tabular}{llcc}
\multicolumn{4}{l}{ TABLE 1: } \\
\hline Variable & Category & Frequency $(\boldsymbol{f})$ & Percentage (\%) \\
\hline Race & African & 396 & 29.1 \\
& Coloured & 183 & 13.4 \\
& Indian & 125 & 9.2 \\
& White & 658 & 48.3 \\
Gender & Female & 407 & 29.9 \\
& Male & 955 & 70.1 \\
Age (in years) & $0-19$ & 0 & 0.0 \\
& $20-29$ & 106 & 7.8 \\
& $30-39$ & 406 & 29.8 \\
& $40-49$ & 563 & 41.3 \\
& $50-59$ & 276 & 20.3 \\
& $60-79$ & 11 & 0.8 \\
Occupational & Manager & 65 & 4.8 \\
& Information technology & 89 & 6.5 \\
& Technicians & 605 & 44.4 \\
& Sales & 238 & 17.5 \\
& Supervisory & 222 & 16.3 \\
& Clerical or admin & 143 & 10.5 \\
\hline
\end{tabular}

$n=1362$. given the published empirical testing, the PC08 was selected as the most appropriate measure aligned to the research purpose The PC08 consisted of 15 questions, which cover the five occupational culture dimensions, namely Power, Time, Risk, Gender (Service) and Team. Three questions are included for each of the dimensions (Herkenhoff, 2010).

Amendments to the original measurement tool: Slightly low reliabilities were calculated for some of the subscales of the PC08. To strengthen the measurement tool's psychometric properties, additional items were incorporated for all subscales. The Environment component of the Gender dimension was further incorporated in the questionnaire for the study purpose. Given the amendments, the proposed PC10 questionnaire was subjected to rigorous measurement model analysis as part of the study.

Validity or reliability: The reliability analysis results are shown in Table 2. As highlighted in the table, with the exception of the Power subscale (0.59), all the occupational culture subscales on the PC10 questionnaire attained a Cronbach's coefficient alpha value of at least 0.70 as recommended (Pallant, 2007). Subject matter experts confirmed the face validity of the questionnaire.

Reward preference questionnaire: Background to the questionnaire: The South African reward preference questionnaire (SARM10) is based on the RM98 remuneration questionnaire, which measured employee remuneration preferences (Herkenhoff, 2000, 2009). The RM98 questionnaire considered 7 remuneration elements and consisted of 17 items, namely 2 to 4 items per element (Herkenhoff, 2000). The seven remuneration elements are hierarchical, pension, job security, work hours, welfare, team pay and team all (Herkenhoff, 2000).

Amendments to the original measurement tool: The RM98 questionnaire was revised to align to the modern approach to total reward as proposed by WorldatWork (2008). The RM98 was further American based and was amended to align to the South African context. Additional items were incorporated to the RM98 in order to address lower-than-desired reliabilities, which were reported across some of the subscales. Given the amendments, the SARM10 questionnaire was subjected to rigorous measurement model analysis.

Validity or reliability: Reliability analysis results for the final study are shown in Table 3. As indicated in the table,

TABLE 2: PC08 (Herkenhoff, 2010) and PC10 subscale reliabilities.

\begin{tabular}{|c|c|c|c|c|}
\hline \multirow[t]{2}{*}{ Subscale } & \multicolumn{2}{|r|}{ PC08 } & \multicolumn{2}{|r|}{ PC10 } \\
\hline & $\begin{array}{l}\text { Number of } \\
\text { items }\end{array}$ & $\begin{array}{l}\text { Cronbach's alpha } \\
\text { coefficient }\end{array}$ & $\begin{array}{l}\text { Number of } \\
\text { items }\end{array}$ & $\begin{array}{l}\text { Cronbach's alpha } \\
\text { coefficient }\end{array}$ \\
\hline Power & 3 & 0.82 & 8 & $0.59 \dagger$ \\
\hline Time & 3 & 0.75 & 7 & 0.78 \\
\hline Risk & 3 & $0.65 \dagger$ & 7 & 0.74 \\
\hline Gender (Service) & 3 & $0.49 \dagger$ & 7 & 0.75 \\
\hline Gender (Environment) & - & - & 7 & 0.80 \\
\hline Team & 3 & 0.78 & 7 & 0.74 \\
\hline
\end{tabular}

$\dagger$, Cronbach's alpha coefficients $<0.70$. 
TABLE 3: RM98 (Herkenhoff, 2000) and SARM10 subscale reliabilities.

\begin{tabular}{lcccccc}
\hline Subscale & \multicolumn{2}{c}{ RM98 } & & \multicolumn{2}{c}{ SARM10 } \\
\cline { 2 - 3 } \cline { 5 - 6 } & $\begin{array}{c}\text { Number } \\
\text { of } \\
\text { items }\end{array}$ & $\begin{array}{c}\text { Cronbach's } \\
\text { alpha } \\
\text { coefficient }\end{array}$ & $\begin{array}{c}\text { Number } \\
\text { of } \\
\text { items }\end{array}$ & $\begin{array}{c}\text { Cronbach's } \\
\text { alpha } \\
\text { coefficient }\end{array}$ \\
\hline Guaranteed package & - & - & 8 & 0.74 \\
Short-term incentives & - & - & & 7 & 0.85 \\
Retirement or pension & 2 & 0.81 & & 7 & 0.81 \\
Hierarchical (RM98) & 3 & 0.89 & & - & - \\
Job-level-based benefits (SARM10) & - & - & & 7 & 0.75 \\
Welfare (RM98) & 2 & 0.88 & & - & - \\
Family-related benefits (SARM10) & - & - & & 7 & 0.81 \\
Work hours & 2 & $0.59 \dagger$ & & 8 & 0.75 \\
Performance and recognition & - & - & & 7 & 0.87 \\
Career and development & - & - & & 7 & 0.81 \\
Job security & 2 & $0.65 \dagger$ & & 7 & 0.85 \\
Team pay & 2 & 0.85 & & 6 & 0.69 \\
Team all (RM98) & 4 & 0.92 & & - & - \\
Team equal (SARM10) & - & - & & 6 & 0.90 \\
\hline
\end{tabular}

$\dagger$, Cronbach's alpha coefficients $<0.70$.

reliabilities for the Job security (0.65) and Work hours (0.59) subscales of the original RM98 were lower than desired. Excepting the Team pay subscale (0.69), reliabilities for the SARM10 reward subscales were acceptable. Face validity of the SARM10 questionnaire was confirmed by reward experts.

\section{Questionnaire pre-testing}

The proposed research questionnaire underwent pre-testing and two pilot studies. Each pilot consisted of 820 employees. A stratified sampling procedure ensured that employees from the identified occupational groups were represented appropriately. A total of 160 responses were received in the first pilot study, and 146 of these responses were complete (19.5\% response rate). For the second pilot study, 139 complete responses were received ( $17 \%$ response rate).

The computerised IBM SPSS Statistics package, version 18 (IBM, 2011), was utilised to conduct initial statistical analyses. This incorporated exploratory factor analysis with maximum likelihood and oblique rotations. Cronbach's coefficient alpha was calculated in terms of the reliability and item analysis. Results from pilot study 1 revealed very different properties to those reported for the original measurement tools (i.e. the PC08 and RM98). Reliabilities across most of the subscales were below cut-off values, and the factor analyses results were problematic for a number of the subscales. Problematic items were reworked and additional items per subscale were added. The revised questionnaire was retested. Results of the second pilot study revealed improved reliabilities across most of the subscales. A few of the subscales remained problematic with below-average reliabilities (namely, the Power, Risk and Team occupational culture subscales and the Job-level-based benefits, Work hours and Team pay reward subscales). A few factor analysis issues remained. The questionnaire was amended to address the problems highlighted through the factor analysis.

\section{Research procedure}

Data collection for the two pilot studies took place over a 5-day period each, while data collection for the main study took place over a 10-day period. In collecting the study data, an email was sent to the sample which introduced the research, its purpose and objective. The email included the survey weblink and completion instructions. It further highlighted that participation was voluntary and that responses would be used for research purposes alone. Reminder emails were distributed to the sample in the main study halfway through the data collection period (i.e. after 5 days).

\section{Statistical analysis}

The computerised IBM SPSS Statistics package, version 18 (IBM, 2011), was utilised to calculate descriptive statistics and in conducting exploratory factor analysis, reliability analysis and confirmatory factor analysis. WINSTEPS, version 3.71.0 (Linacre, 2011), was utilised in conducting Rasch rating scale analysis in order to consider the contribution of each item towards the internal consistency.

\section{Results \\ Descriptive statistics}

Descriptive statistics for the Occupational culture questionnaire (PC10) are included in Table 4. The highest mean score (4.50) was reported for Item A19 on the Environment subscale ('I make decisions in my job without clearly defined guidelines'). Item A11 ('I would rather work less hours and get less pay') displayed the lowest mean score (2.79). The majority of the items displayed a negative skewness. This represented a positive response pattern (Pallant, 2007). Robust maximum likelihood (RML) was utilised in the further analyses to cater for skewness in the data.

SARM10 descriptive statistics are shown in Table 5. The highest mean score (4.51) was reported for Item D7 on the Performance and recognition subscale ('Being recognised for my skills and abilities is important to me'). Item B26 ('I would rather work less hours and get less pay') reported the lowest mean score (1.93); this item was in the Work hours subscale. The majority of the items displayed a negative skewness representing a positive response pattern (Pallant, 2007). RML was utilised in the further analyses to cater for skewness in the data.

\section{Structural equation modelling analyses}

In line with the study purpose, analyses focused on testing the proposed SEM theoretical model. The first step consisted of assessing the model fit with specific consideration to the standardised residuals and the 'goodness of fit' statistical analysis. In terms of the proposed theoretical model, 1301 statistically significant standardised residuals with an absolute value greater than $2.58(p<0.01)$ were detected in the reproduced residual matrix. The output of the goodness of fit analysis is reflected in Table 6. As reflected, the root mean square error of approximation $=0.040, p=1.000,90 \%$ confidence interval $[0.039,0.040]$ and was indicative of good 
TABLE 4: Descriptive statistics for the occupational culture scale (PC10).

\begin{tabular}{|c|c|c|c|c|c|c|c|c|c|}
\hline Subscale & Item & $N$ : Valid & $N$ : Missing & Mean & Median & Mode & $\begin{array}{l}\text { Standard } \\
\text { deviation }\end{array}$ & Skewness & Kurtosis \\
\hline \multirow[t]{8}{*}{ Power } & $\mathrm{A} 1$ & 1362 & 0 & 3.95 & 4.00 & 4 & 0.866 & -1.153 & 1.734 \\
\hline & $\mathrm{A} 3$ & 1362 & 0 & 3.17 & 3.00 & 4 & 1.075 & -0.192 & -0.757 \\
\hline & A4 & 1362 & 0 & 3.67 & 4.00 & 4 & 0.959 & -0.950 & 0.601 \\
\hline & A21 & 1362 & 0 & 4.06 & 4.00 & 4 & 0.819 & -1.228 & 2.468 \\
\hline & $\mathrm{A} 23$ & 1362 & 0 & 3.20 & 3.00 & 3 & 1.085 & -0.113 & -0.719 \\
\hline & B1 & 1284 & 78 & 3.28 & 3.00 & 3 & 0.811 & -0.252 & -0.019 \\
\hline & B2 & 1284 & 78 & 3.59 & 4.00 & 4 & 1.074 & -0.384 & -0.802 \\
\hline & B3 & 1284 & 78 & 3.62 & 4.00 & 4 & 1.081 & -0.441 & -0.778 \\
\hline \multirow[t]{7}{*}{ Risk } & A11 & 1362 & 0 & 2.79 & 3.00 & 2 & 1.154 & 0.229 & -0.934 \\
\hline & A13 & 1362 & 0 & 3.19 & 3.00 & 4 & 1.058 & -0.056 & -0.913 \\
\hline & A14 & 1362 & 0 & 3.11 & 3.00 & 2 & 1.092 & 0.037 & -0.924 \\
\hline & A15 & 1362 & 0 & 3.15 & 3.00 & 4 & 1.090 & -0.163 & -0.902 \\
\hline & A16 & 1362 & 0 & 3.33 & 4.00 & 4 & 1.098 & -0.291 & -0.818 \\
\hline & B6 & 1284 & 78 & 2.69 & 2.00 & 2 & 1.089 & 0.421 & -0.678 \\
\hline & B7 & 1284 & 78 & 3.90 & 4.00 & 4 & 0.820 & -0.819 & 0.913 \\
\hline \multirow[t]{7}{*}{ Service } & A9 & 1362 & 0 & 4.23 & 4.00 & 4 & 0.832 & -1.345 & 2.317 \\
\hline & A17 & 1362 & 0 & 3.80 & 4.00 & 4 & 0.905 & -0.929 & 0.795 \\
\hline & A18 & 1362 & 0 & 4.26 & 4.00 & 4 & 0.756 & -1.312 & 2.879 \\
\hline & $\mathrm{A} 20$ & 1362 & 0 & 4.19 & 4.00 & 4 & 0.813 & -1.183 & 1.924 \\
\hline & A25 & 1362 & 0 & 4.26 & 4.00 & 4 & 0.766 & -1.440 & 3.489 \\
\hline & B8 & 1284 & 78 & 4.48 & 5.00 & 5 & 0.693 & -1.600 & 3.768 \\
\hline & B9 & 1284 & 78 & 4.29 & 4.00 & 5 & 0.870 & -1.532 & 2.745 \\
\hline \multirow[t]{5}{*}{ Environment } & $\mathrm{A} 2$ & 1362 & 0 & 4.12 & 4.00 & 4 & 0.825 & -1.170 & 1.925 \\
\hline & A19 & 1362 & 0 & 4.50 & 5.00 & 5 & 0.658 & -1.646 & 4.703 \\
\hline & A26 & 1362 & 0 & 4.39 & 5.00 & 5 & 0.758 & -1.627 & 3.865 \\
\hline & $A 27$ & 1362 & 0 & 4.33 & 4.00 & 4 & 0.719 & -1.178 & 2.098 \\
\hline & A29 & 1362 & 0 & 4.34 & 4.00 & 5 & 0.739 & -1.359 & 2.898 \\
\hline \multirow[t]{9}{*}{ Time } & B12 & 1284 & 78 & 4.45 & 4.00 & 5 & 0.602 & -0.846 & 1.184 \\
\hline & B13 & 1284 & 78 & 4.24 & 4.00 & 4 & 0.821 & -1.124 & 1.306 \\
\hline & A6 & 1362 & 0 & 4.00 & 4.00 & 4 & 0.884 & -1.034 & 1.208 \\
\hline & A7 & 1362 & 0 & 3.77 & 4.00 & 4 & 0.956 & -0.837 & 0.405 \\
\hline & A8 & 1362 & 0 & 3.83 & 4.00 & 4 & 0.983 & -0.884 & 0.436 \\
\hline & A10 & 1362 & 0 & 4.08 & 4.00 & 4 & 0.829 & -1.156 & 2.047 \\
\hline & A12 & 1362 & 0 & 3.13 & 3.00 & 4 & 1.057 & -0.099 & -0.910 \\
\hline & B4 & 1284 & 78 & 3.73 & 4.00 & 4 & 0.943 & -0.782 & 0.274 \\
\hline & B5 & 1284 & 78 & 3.95 & 4.00 & 4 & 0.811 & -0.921 & 1.345 \\
\hline \multirow[t]{7}{*}{ Team } & A5 & 1362 & 0 & 3.56 & 4.00 & 4 & 1.070 & -0.619 & -0.313 \\
\hline & A22 & 1362 & 0 & 4.21 & 4.00 & 4 & 0.801 & -1.257 & 2.334 \\
\hline & A24 & 1362 & 0 & 3.95 & 4.00 & 4 & 0.952 & -1.048 & 0.869 \\
\hline & A28 & 1362 & 0 & 3.95 & 4.00 & 4 & 0.954 & -1.111 & 1.229 \\
\hline & $\mathrm{A} 30$ & 1362 & 0 & 3.64 & 4.00 & 4 & 1.086 & -0.534 & -0.499 \\
\hline & B10 & 1284 & 78 & 4.08 & 4.00 & 4 & 0.913 & -1.208 & 1.592 \\
\hline & B11 & 1284 & 78 & 3.62 & 4.00 & 4 & 1.129 & -0.674 & -0.390 \\
\hline
\end{tabular}

fit. In addition, the standardised root-mean-square residual value of 0.069 provided support for good model fit. However, lower-than-desired comparative fit index and Tucker-Lewis index values of 0.777 and 0.768 were found; therefore, only partial empirical support was reported for the fit of the proposed theoretical model.

Focus was given to the Gamma parameters or regression lines in considering the model parameter estimates of the proposed theoretical model. Of particular interest were the size, direction and statistical significance of the relationships. Table 7 presents the standardised and unstandardised Gamma values. Nine of the hypothesised regressions showed statistically significant relationships, with the majority of these values displaying statistical significance at the $p<0.01$ level. All the statistically significant relationships were positive, with the exception of
$\mathrm{H}_{13}$ (Service and Family-related benefits) and $\mathrm{H}_{15}$ (Time and Short-term incentives), which reported standardised Gamma values of $-0.168(p<0.01)$ and $-0.089(p<0.05)$, respectively. While a negative relationship was hypothesised between Time and Short-term incentives $\left(\mathrm{H}_{15}\right)$, a positive relationship was hypothesised between Service and Family-related benefits $\left(\mathrm{H}_{13}\right)$. The direction of the relationship is therefore unexpected.

Model $R$-square values or commonalities were considered, given that in some cases it was found that dependent variables in the proposed theoretical model had more than one independent variable contributing to the reported variance. Cohen's (1988) guidelines assisted in interpreting the effect size, whereby $r=0.10$ reflected a small effect size, $r=0.30$ a medium effect size and $r=0.50$ a large effect size. The Model $R$-square values for the proposed theoretical model are reflected 
TABLE 5: Descriptive statistics for the reward preference scale (SARM10).

\begin{tabular}{|c|c|c|c|c|c|c|c|c|c|}
\hline Subscale & Item & $N$ : Valid & $N$ : Missing & Mean & Median & Mode & Standard deviation & Skewness & Kurtosis \\
\hline \multirow{8}{*}{$\begin{array}{l}\text { Guaranteed } \\
\text { package }\end{array}$} & C15 & 1259 & 103 & 4 & 4 & 4 & 0.808 & -0.968 & 1.606 \\
\hline & $\mathrm{C} 20$ & 1259 & 103 & 4.03 & 4 & 4 & 0.781 & -0.916 & 1.66 \\
\hline & D11 & 1250 & 112 & 4.35 & 4 & 4 & 0.693 & -1.034 & 1.75 \\
\hline & D21 & 1250 & 112 & 4.18 & 4 & 4 & 0.735 & -0.801 & 1.038 \\
\hline & D22 & 1250 & 112 & 3.11 & 3 & 3 & 1.031 & -0.124 & -0.34 \\
\hline & D23 & 1250 & 112 & 4.07 & 4 & 4 & 0.924 & -0.939 & 0.562 \\
\hline & D24 & 1250 & 112 & 3.79 & 4 & 4 & 0.936 & -0.611 & 0.077 \\
\hline & D25 & 1250 & 112 & 4.27 & 4 & 4 & 0.6 & -0.462 & 0.806 \\
\hline \multirow{7}{*}{$\begin{array}{l}\text { Short-term } \\
\text { incentives }\end{array}$} & B18 & 1284 & 78 & 3.66 & 4 & 4 & 1.045 & -0.645 & -0.149 \\
\hline & B19 & 1284 & 78 & 3.79 & 4 & 4 & 0.991 & -0.831 & 0.319 \\
\hline & $\mathrm{C} 4$ & 1259 & 103 & 3.4 & 4 & 4 & 1.109 & -0.308 & -0.717 \\
\hline & $\mathrm{C} 5$ & 1259 & 103 & 3.52 & 4 & 4 & 1.006 & -0.458 & -0.337 \\
\hline & $\mathrm{C} 17$ & 1259 & 103 & 3.59 & 4 & 4 & 1.024 & -0.563 & -0.219 \\
\hline & D3 & 1250 & 112 & 3.46 & 4 & 4 & 0.975 & -0.431 & -0.319 \\
\hline & D30 & 1250 & 112 & 3.92 & 4 & 4 & 0.827 & -0.647 & 0.595 \\
\hline \multirow[t]{7}{*}{ Pension } & B17 & 1284 & 78 & 3.24 & 3 & 4 & 1.179 & -0.248 & -0.801 \\
\hline & B20 & 1284 & 78 & 3.45 & 4 & 4 & 1.116 & -0.371 & -0.615 \\
\hline & B23 & 1284 & 78 & 4.4 & 5 & 5 & 0.714 & -1.467 & 3.433 \\
\hline & $\mathrm{C} 8$ & 1259 & 103 & 3.35 & 3 & 3 & 1.019 & -0.173 & -0.494 \\
\hline & D27 & 1250 & 112 & 3.11 & 3 & 3 & 1.11 & -0.005 & -0.733 \\
\hline & D28 & 1250 & 112 & 3.18 & 3 & 3 & 1.016 & -0.017 & -0.566 \\
\hline & D29 & 1250 & 112 & 3.58 & 4 & 4 & 0.938 & -0.553 & 0.086 \\
\hline \multirow{7}{*}{$\begin{array}{l}\text { Job-level-based } \\
\text { benefits }\end{array}$} & B14 & 1284 & 78 & 2.84 & 3 & 1 & 1.453 & 0.115 & -1.408 \\
\hline & B21R & 1284 & 78 & 2.32 & 2 & 1 & 1.371 & 0.625 & 1 \\
\hline & B29 & 1284 & 78 & 1.99 & 2 & 1 & 1.18 & 0.959 & -0.17 \\
\hline & $\mathrm{C} 27$ & 1259 & 103 & 3.84 & 4 & 4 & 0.878 & -0.869 & 0.983 \\
\hline & $\mathrm{C} 28$ & 1259 & 103 & 3.71 & 4 & 4 & 0.99 & -0.606 & -0.061 \\
\hline & D9 & 1250 & 112 & 2.47 & 2 & 1 & 1.201 & 0.294 & -0.992 \\
\hline & D12 & 1250 & 112 & 2.71 & 3 & 2 & 1.284 & 0.175 & -1.18 \\
\hline \multirow{7}{*}{$\begin{array}{l}\text { Family-related } \\
\text { benefits }\end{array}$} & B25 & 1284 & 78 & 3.17 & 3 & 3 & 0.957 & -0.044 & -0.313 \\
\hline & B30 & 1284 & 78 & 4.03 & 4 & 4 & 0.964 & -1.034 & 0.879 \\
\hline & $\mathrm{C} 1$ & 1259 & 103 & 3.74 & 4 & 4 & 0.834 & -0.568 & 0.363 \\
\hline & $\mathrm{C} 3$ & 1259 & 103 & 3.81 & 4 & 4 & 0.863 & -0.58 & 0.134 \\
\hline & $\mathrm{C} 21$ & 1259 & 103 & 3.41 & 3 & 3 & 0.898 & -0.175 & -0.217 \\
\hline & $\mathrm{C} 22$ & 1259 & 103 & 3.93 & 4 & 4 & 0.985 & -0.87 & 0.465 \\
\hline & $\mathrm{C} 23$ & 1259 & 103 & 3.36 & 3 & 3 & 1.095 & -0.225 & -0.602 \\
\hline \multirow[t]{7}{*}{ Job security } & B15 & 1284 & 78 & 3.3 & 3 & 3 & 1.148 & -0.3 & -0.638 \\
\hline & B16 & 1284 & 78 & 3.18 & 3 & 4 & 1.197 & -0.291 & -0.813 \\
\hline & B24 & 1284 & 78 & 3.1 & 3 & 3 & 1.21 & -0.023 & -0.966 \\
\hline & $\mathrm{C} 13$ & 1259 & 103 & 2.91 & 3 & 3 & 1.097 & 0.126 & -0.703 \\
\hline & $\mathrm{C} 24$ & 1259 & 103 & 3.4 & 4 & 4 & 1.032 & -0.362 & -0.431 \\
\hline & $\mathrm{C} 25$ & 1259 & 103 & 4.17 & 4 & 4 & 0.751 & -1.065 & 2.187 \\
\hline & C26 & 1259 & 103 & 3.42 & 4 & 4 & 1.053 & -0.282 & -0.589 \\
\hline \multirow[t]{8}{*}{ Work hours } & B22 & 1284 & 78 & 3.97 & 4 & 4 & 1.006 & -0.933 & 0.471 \\
\hline & B26 & 1284 & 78 & 1.93 & 2 & 2 & 0.989 & 1.169 & 1.143 \\
\hline & B27 & 1284 & 78 & 3.3 & 3 & 4 & 1.16 & -0.284 & -0.787 \\
\hline & $\mathrm{C} 7$ & 1259 & 103 & 3.98 & 4 & 4 & 0.813 & -0.756 & 0.83 \\
\hline & C18 & 1259 & 103 & 3.62 & 4 & 4 & 1.053 & -0.628 & -0.171 \\
\hline & C29 & 1259 & 103 & 3.76 & 4 & 4 & 0.976 & -0.674 & 0.07 \\
\hline & С30 & 1259 & 103 & 3.97 & 4 & 4 & 0.771 & -0.739 & 1.107 \\
\hline & D1 & 1250 & 112 & 2.89 & 3 & 3 & 0.953 & 0.23 & -0.287 \\
\hline \multirow{7}{*}{$\begin{array}{l}\text { Career and } \\
\text { development }\end{array}$} & D4 & 1250 & 112 & 4.1 & 4 & 4 & 0.74 & -0.822 & 1.318 \\
\hline & D5 & 1250 & 112 & 3.96 & 4 & 4 & 0.862 & -0.84 & 0.767 \\
\hline & D8 & 1250 & 112 & 4.4 & 5 & 5 & 0.716 & -1.237 & 0.974 \\
\hline & D13 & 1250 & 112 & 3.36 & 3 & 3 & 1.045 & -0.129 & -0.628 \\
\hline & D15 & 1250 & 112 & 4.32 & 4 & 4 & 0.674 & -1.109 & 2.786 \\
\hline & D16 & 1250 & 112 & 4.37 & 4 & 4 & 0.636 & -0.942 & 2.131 \\
\hline & D19 & 1250 & 112 & 3.52 & 3 & 3 & 0.992 & -0.154 & -0.55 \\
\hline
\end{tabular}


TABLE 5 (Continues...): Descriptive statistics for the reward preference scale (SARM10).

\begin{tabular}{|c|c|c|c|c|c|c|c|c|c|}
\hline Subscale & Item & $N$ : Valid & $N$ : Missing & Mean & Median & Mode & Standard deviation & Skewness & Kurtosis \\
\hline \multirow{7}{*}{$\begin{array}{l}\text { Performance and } \\
\text { recognition }\end{array}$} & D6 & 1250 & 112 & 4.42 & 4 & 4 & 0.562 & -0.409 & -0.138 \\
\hline & D7 & 1250 & 112 & 4.51 & 5 & 5 & 0.565 & -0.755 & 0.512 \\
\hline & D10 & 1250 & 112 & 4.49 & 5 & 5 & 0.619 & -1.096 & 1.837 \\
\hline & D14 & 1250 & 112 & 4.36 & 4 & 4 & 0.581 & -0.489 & 0.781 \\
\hline & D17 & 1250 & 112 & 4.37 & 4 & 4 & 0.616 & -0.68 & 1.012 \\
\hline & D18 & 1250 & 112 & 4.39 & 4 & 4 & 0.623 & -0.837 & 1.458 \\
\hline & D20 & 1250 & 112 & 4.3 & 4 & 4 & 0.634 & -0.624 & 0.857 \\
\hline \multirow[t]{6}{*}{ Team pay } & B28 & 1284 & 78 & 3.27 & 3 & 4 & 1.06 & -0.388 & -0.394 \\
\hline & $\mathrm{C} 2$ & 1259 & 103 & 4.02 & 4 & 4 & 0.981 & -1.186 & 1.134 \\
\hline & C6 & 1259 & 103 & 3.16 & 3 & 4 & 1.225 & -0.246 & -1.002 \\
\hline & $\mathrm{C} 14$ & 1259 & 103 & 3.47 & 4 & 4 & 0.95 & -0.539 & -0.036 \\
\hline & C19 & 1259 & 103 & 3.41 & 4 & 4 & 0.99 & -0.401 & -0.248 \\
\hline & D26 & 1250 & 112 & 3.57 & 4 & 4 & 0.999 & -0.475 & -0.21 \\
\hline \multirow[t]{5}{*}{ Team equal } & $\mathrm{CP}$ & 1259 & 103 & 3.66 & 4 & 4 & 1.174 & -0.655 & -0.481 \\
\hline & $\mathrm{C} 11$ & 1259 & 103 & 3.51 & 4 & 4 & 1.274 & -0.443 & -1.009 \\
\hline & $\mathrm{C} 12$ & 1259 & 103 & 3.38 & 4 & 4 & 1.236 & -0.278 & -1.05 \\
\hline & C16 & 1259 & 103 & 3.21 & 3 & 4 & 1.213 & -0.064 & -1.089 \\
\hline & D2 & 1250 & 112 & 3.52 & 4 & 4 & 1.091 & -0.503 & -0.626 \\
\hline
\end{tabular}

TABLE 6: Goodness of fit statistics for the proposed structural equation modelling theoretical model.

\begin{tabular}{|c|c|c|c|c|c|c|c|c|c|}
\hline \multirow[t]{2}{*}{$p$ value } & \multicolumn{2}{|c|}{ Chi-square test of model fit } & \multirow{2}{*}{$\begin{array}{l}\text { Scaling correction } \\
\text { factor for RML }\end{array}$} & \multicolumn{2}{|r|}{ RMSEA } & \multirow[t]{2}{*}{$90 \% \mathrm{Cl}$} & \multicolumn{2}{|c|}{$\mathrm{CFI} / \mathrm{TLI}$} & \multirow[t]{2}{*}{ SRMR value } \\
\hline & Value & Degrees of freedom & & Estimate & $p$ value RMSEA $(\leq 0.05)$ & & CFI & TLI & \\
\hline 0 & 13468.5 & 4472 & 1.183 & 0.04 & 1 & $0.039,0.040$ & 0.777 & 0.768 & 0.069 \\
\hline
\end{tabular}

RML, robust maximum likelihood; RMSEA, root mean square error of approximation; Cl, confidence interval; CFI, comparative fit index; TLI, Tucker-Lewis index; SRMR, standardised rootmean-square residual.

TABLE 7: Gamma parameters for the proposed structural equation modelling theoretical model.

\begin{tabular}{lcc}
\hline Hypothesis & Standardised Gamma & Unstandardised Gamma \\
\hline $\mathrm{H}_{1}$ & -0.098 & -0.548 \\
$\mathrm{H}_{2}$ & 0.022 & 0.066 \\
$\mathrm{H}_{3}$ & 0.025 & 0.067 \\
$\mathrm{H}_{4}$ & 0.044 & 0.024 \\
$\mathrm{H}_{5}$ & 0.064 & 0.067 \\
$\mathrm{H}_{6}$ & $0.087^{*}$ & $0.079 *$ \\
$\mathrm{H}_{7}$ & -0.030 & -0.035 \\
$\mathrm{H}_{8}$ & $0.328 * *$ & $0.398^{* *}$ \\
$\mathrm{H}_{9}$ & $0.272^{* *}$ & $0.295^{* *}$ \\
$\mathrm{H}_{10}$ & $0.251^{* *}$ & $0.491^{* *}$ \\
$\mathrm{H}_{11}$ & $0.308^{* *}$ & $0.381^{* *}$ \\
$\mathrm{H}_{12}$ & -0.085 & -0.137 \\
$\mathrm{H}_{13}$ & $-0.168^{* *}$ & $-0.170^{*}$ \\
$\mathrm{H}_{14}$ & 0.018 & 0.024 \\
$\mathrm{H}_{15}$ & $-0.089 *$ & $-0.102^{*}$ \\
$\mathrm{H}_{16}$ & $0.250^{* *}$ & $0.244^{* *}$ \\
$\mathrm{H}_{17}$ & $0.066^{*}$ & $0.096^{*}$ \\
\hline$* p<0.05 * *, p<0.01$. & & \\
\hline
\end{tabular}

in Table 8. As can be seen, results revealed statistically significant model R-square values in that Power and Environment together explain $11.2 \%$ variance in Performance and recognition. Power and Environment combined explain $7.9 \%$ variance in Career and development. The Team occupational culture subscale explains $6.3 \%$ of the variance in Team pay, and Environment and Service jointly explain $5.8 \%$ variance in Family-related benefits. Work Hours, Environment and Service collectively explain 4.3\% of the variance therein. Relatively small effect sizes were found.
TABLE 8: $R$-square values for the proposed structural equation modelling theoretical model.

\begin{tabular}{lcc}
\hline Latent variable & Model $\boldsymbol{R}$-square & $\boldsymbol{p}$ value \\
\hline Guaranteed package & 0.002 & 0.584 \\
Short-term incentives & 0.012 & 0.159 \\
Pension & 0.005 & 0.352 \\
Job-level-based benefits & 0.010 & 0.346 \\
Family-related benefits & $0.058^{* *}$ & 0.004 \\
Job security & 0.001 & 0.692 \\
Work hours & $0.043^{*}$ & 0.007 \\
Performance and recognition & $0.112^{* *}$ & 0.000 \\
Career and development & $0.079^{* *}$ & 0.000 \\
Team equal & 0.004 & 0.331 \\
Team pay & $0.063^{* *}$ & 0.002 \\
\hline
\end{tabular}

$*, p<0.05 ; * *, p<0.01$.

Model $R$-square values were not statistically significant for the Guaranteed package, Short-term incentives, Pension, Joblevel-based benefits, Job security, and Team equal reward subscales. Measurement issues were reported for the dependent variable measurement model relating to the Guaranteed package, Short-term incentives, Pension, Job-level-based benefits and Team equal subscales. Issues around model fit were also cited for these particular subscales. The lack of statistical significance of these $R$-square values could therefore be measurement related. With regards to job security, Chiang (2005) suggests that a preference in this regard is typically influenced by broader external or contextual factors rather than culture values, and this may assist in understanding the lack of statistical significance with regard to the Job security reward element at a model level. To this end, environmental elements such as the economic position as well as values and practices in the organisation, rather than a sole focus on cultural issues, could have an influence on the job security reward element. 


\section{Hypothesis testing}

Hypotheses $\mathrm{H}_{1}-\mathrm{H}_{17}$ were formulated relating to the proposed relationships between the occupational culture dimensions and reward preferences. As proposed by Pallant (2007), in reviewing the hypothesised relationships, the practical and statistical significance of relationships was considered. In terms of practical significance, of particular concern is the extent of the correlation and direction of the relationship. Guidelines proposed by Cohen (1988) assisted in guiding the interpretation of the size of the correlation $(r)$, whereby $r=0.10$ indicated a small effect size, $r=0.30$ indicated a medium effect size and $r=0.50$ and greater indicated a large effect size. Statistical significance considers the probability that the relationship exists and a cut-off of $p<0.05$ was applied. $R$-square values provide insight into effect sizes. $R$-square values and commonalities were calculated and aided in the hypotheses testing.

Based on the output of the statistical analyses, 7 of the 17 formulated hypotheses were empirically supported. This pertained to the relationships between the Environment occupational culture dimension and Performance and recognition $\left(\mathrm{H}_{8}\right)$, Career and development $\left(\mathrm{H}_{9}\right)$, Work hours $\left(\mathrm{H}_{10}\right)$ and Family-related benefits $\left(\mathrm{H}_{11}\right)$, as well as the occupational culture dimension Time and Short-term incentives $\left(\mathrm{H}_{15}\right)$ and the Team occupational culture dimension and Team pay $\left(\mathrm{H}_{16}\right)$ and Team equal $\left(\mathrm{H}_{17}\right)$.

Very significant positive relationships with a small effect size were evident for Environment and Performance and recognition $\left(\mathrm{H}_{8}\right)$, Environment and Career and development $\left(\mathrm{H}_{9}\right)$, Environment and Work hours $\left(\mathrm{H}_{10}\right)$ and Environment and Family-related benefits $\left(\mathrm{H}_{11}\right)$. The variances explained in Performance and Recognition, Career and development, Work hours and Family-related benefits were 11.2\%, 7.9\%, $4.3 \%$ and $5.8 \%$, respectively. A significant negative relationship between Time and Short-term incentives (hypothesis $\mathrm{H}_{15}$ ) was evident with a small effect size. A 1.2\% variance was explained in Short-term incentives. A very significant positive relationship was identified for hypothesis $\mathrm{H}_{16}$, namely the relationship between Team and Team pay. A small effect size was evident, and $6.3 \%$ variance was explained in Team pay. A significant positive relationship between Team and Team equal (hypothesis $\mathrm{H}_{17}$ ) was found. A very small effect size was evident and $0.4 \%$ variance was explained in Team equal.

Although statistically significant relationships were found for hypotheses $\mathrm{H}_{6}$ (Risk and Short-term incentives) and $\mathrm{H}_{13}$ (Service and Family-related benefits), the direction of these relationships was not as predicted, and as such, these hypotheses could not be empirically proven. The remaining proposed hypotheses did not achieve the required level of statistical significance and could therefore not be empirically validated.

\section{Discussion}

All the hypothesised relationships in the proposed SEM theoretical model pertaining to the Environment occupational culture dimension were empirically corroborated. Therefore, a positive relationship was found between the Environment occupational culture dimension and a number of the reward preferences, namely, Performance and recognition, Career and development, Work hours and Family-related benefits. The Environment occupational culture dimension has not been researched previously, and as such, the findings are of particular interest. The findings are in line with the position that environment and work-life balance play a key role for knowledge workers in the information technology sector (Bussin \& Toerien, 2015; Johns \& Gratton, 2013) and the value that employees place on career growth and development (Nienaber et al., 2011; Schlechter et al., 2015). It is interesting to observe that the reward elements in these relationships (that is, in hypotheses $\mathrm{H}_{8}$ to $\mathrm{H}_{11}$ ) are largely non-financial reward based. Non-financial reward elements are related to emotional factors, which are seen as contributors to employee engagement (Heger, 2007). These emotional factors relate to aspects such as work achievement, work relationships, work climate and the opportunity to learn and grow (Shuck, Rocco \& Albornoz, 2011). The significant findings on these particular hypotheses could potentially be seen as further evidence in support of the relationship between non-financial rewards and employee engagement.

The research highlighted a negative relationship between Time and Short-term incentives (hypothesis $\mathrm{H}_{15}$ ). The negative relationship suggests that occupational groups that display a longer term orientation towards time show a lesser preferences for short-term rewards, for example on-the-spot incentives. Previous occupational culture research highlighted a short-term orientation specifically for the Information Technology occupational group, which indicates a preference for feedback which is immediate rather than postponed (Herkenhoff, 2010). The present findings are therefore in support of previous findings, albeit interpreted from a reward perspective.

The relationships between the Team occupational culture dimension and the Team pay and Team equal reward elements were also empirically supported. From a national culture perspective, the significant influence of the Individualism-Collectivism dimension on reward systems has previously been recorded. With an alignment between the Team occupational culture and the Individualism-Collectivism national culture dimension, the current results display similar support from an occupational group perspective. Practically, this implies that occupational groups with a team orientation may be inclined to prefer team-based reward practices such as recognition for the group as a whole, teambased awards and equal pay for team members.

\section{Managerial implications}

Findings of the research suggest that evaluating the extent to which an occupational group places the needs of the team above those of the individual may assist organisations in considering a team-based approach to reward. It is probable that those groups that are more concerned about team needs 
will demonstrate a greater preference for a team-based reward approach. This may assist the organisation in decision making regarding pay practices, that is, in opting for individual versus team-based rewards. Furthermore, where risk-based incentives are incorporated as part of the overall reward strategy, the consideration should be given to whether employees are short- or long-term focused. This will assist in aiding maximum impact of adopting an incentive-based reward strategy. In this way, the study provides practical input to organisations and reward professionals in the design of reward strategies and programmes.

Adopting a completely individualised approach to reward is problematic for organisations administratively (Nienaber \& Bussin, 2011). A group approach to reward may be more feasible. In practically implementing such an approach, organisations could consider a fixed basic pay and benefits structure with provision for flexible benefits, which are occupational group and reward preference-based (e.g. this may include the option for short-and/or long-term incentives for the sales occupational group). Based on the findings, this approach may be of particular value to organisations in the implementation of non-financial rewards elements such as Career growth and development, work-life balance and Performance and recognition. This would ease the administrative burden for the organisation while leveraging reward benefit from a retention perspective. Given that turnover levels tend to be higher for ICT staff versus general staff (P-E Corporate Survey, September 2010) and that attracting and retaining knowledge workers remains a challenge (Bussin \& Toerien, 2015; Schlechter et al., 2015), the findings may be of particular relevance for organisations operating in the ICT space.

As previously highlighted, the influence of occupational culture extends further than its influence on reward preferences and resultant reward practices. A consideration of the influence of occupational culture may assist organisations in better understanding not only individual behaviour but also group and organisation behaviour. From a human resource management perspective, an enhanced understanding of behaviour at these three levels may assist organisations in optimising efforts, enhancing performermanager relationships and creating a conducive and motivating work environment.

\section{Limitations of the study and directions for future research}

The research was conducted in one country and one company in order to contain the effects of national and organisational culture. By nature of this research approach, generalisation of the findings has to be arrived at with caution. Despite a sizable sample and adopting a stratified strategy on sampling, the over-representation of the white race group needs to be noted in the interpretation of the final results. Future research should include replication studies as well as broader populations in order to aid the generalisability of the findings. Concerns around the psychometric properties of certain subscales of the measurement tool were acknowledged, and this may have impacted the results incorporating the Joblevel-based benefits and Work hours as well as the Power, Service, and Risk dimensions. Follow-up studies should focus on a further refinement of these measures.

\section{Conclusion}

With workforces becoming more diverse and globalised, the status quo of one-size-for-all cannot possibly last. Reward preferences exist, and much more research is required to better understand these preferences. We know already that reward preferences exist by gender, race, Myers Briggs profile, life cycle, and now we know that it also exists within different occupational groups. Organisations now need to find a way to implement reward choices to ensure optimal retention of staff. This will make them more productive, efficient and profitable.

\section{Acknowledgements Competing interests}

The authors declare that they have no financial or personal relationships which may have inappropriately influenced them in writing this article.

\section{Authors' contributions}

M.B., M.N. and R.N. were the principle investigators and were responsible for the design of the project. M.N. was responsible for field work and writing up the research. M.B., M.N. and R.N. wrote the article.

\section{References}

Ames, G.M., Duke, M.R., Moore, R.S. \& Cunradi, C.B. (2009). Impact of occupational culture on drinking behavior of young adults in the U.S. Navy. Journal of Mixed Methods Research, 3(2), 129-150. http://dx.doi.org/10.1177/1558689808328534

Armstrong, M. (2002). Employee reward. London: Chartered Institute of Personnel and Development.

Armstrong, M., \& Stephens, T. (2005). A handbook of employee reward management and practice. London: Kogan Page.

Bhattacharya, S., \& Mukherjee, R. (2009). Rewards as a key to employee engagement: A comparative study on I.T. professionals. ASBM Journal of Management, 2(1), 160-175.

Bond, M. (1988). Finding unusual dimensions of individual variation in multi-cultural studies of values: The Rokeach and Chinese value surveys. Journal of Personality and Social Psychology, 55, 1009-1015. http://dx.doi.org/10.1037/0022-3514.55.6.1009

Bunton, T.E., \& Brewer, J.L. (2012). Discovering workplace motivators for the millennial generation of IT employees. Proceedings of the ACM 1st Annual Conference on Research in Information Technology, 13-18 October. http://dx.doi.org/10.1145/ Research in Inform
2380790.2380795

Bussin, M (2011). The remuneration handbook for Africa: A practical and informative handbook for managing and recognition in Africa. Randburg, South Africa: Knowres Publishing.

Bussin, M., \& Toerien, W.C. (2015). Influence of reward preferences in attracting, retaining, and motivating knowledge workers in South African information technology companies. Acta Commercii, 15(1), Art. \#290, 13 pages. http://dx.doi. org/10.4102/ac.v15i1.290

Bussin, M., \& Van Rooy, D.J. (2014). Total rewards strategy for a multi-generational workforce in a financial institution. SA Journal of Human Resource Management, 12(1), Art. \#606, 11 pages. http://dx.doi.org/10.4102/sajhrm.v12i1.606

Chiang, F. (2005). A critical examination of Hofstede's thesis and its application to international reward management. The International Journal of Human Resource Management, 16(9), 1545-1563. http://dx.doi.org/10.1080/09585190500239044

Cohen, J. (1988) Statistical power analysis for the behavioral sciences (2nd edn.). Hillsdale, NJ: Lawrence Erlbaum Associates.

Erez, M. (1997). A culture-based model of work motivation. In P. Earley \& M. Erez (Eds.), New perspectives on international industrial/organizational psychology (n.p.). San Francisco, CA: New Lexington Press. 
Heger, B.K. (2007). 'Linking the employment value proposition (EVP) to employee engagement and business outcomes: Preliminary findings from a linkage research pilot study', Organization Development Journal, 25(2), 121-132.

Herkenhoff, L.M. (2000). National remuneration (pay) preferences: Cultural analysis within the Hofstede model. La Vergne, TN: Dissertation.com.

Herkenhoff, L.M. (2004). Culturally tuned emotional intelligence: An effective change management tool? Strategic Change, 13, 73-81. http://dx.doi.org/10.1002/jsc.666

Herkenhoff, L.M. (2009). A socially intelligent approach to global remuneration. World Journal of Management, 1(1), 118-140.

Herkenhoff, L.M. (2010). Professional culture, emotional intelligence and the emotional process model. The Journal of Organizational Leadership and Business, Summer. 2010, 1-30.

Hofstede, G. (1980). Culture's consequences: International differences in work-related values. Beverley Hills, CA: Sage.

Hofstede, G. (1991). Cultures and organizations: Software of the mind. London: McGraw-Hill.

Hofstede, G. (1995). Managerial values. In T. Jackson (Ed.), Cross-cultural managemen (pp. 150-165). Oxford: Butterworth-Heinemann

IBM. (2011) IBM SPSS Statistics Editions. Retrieved July 14, 2015, from http://public dhe.ibm.com/common/ssi/ecm/en/yts03009usen/YTS03009USEN.PDF

Johns, T., \& Gratton, L. (2013). The third wave of virtual work. Harvard Business Review, 91, 66-72.

Lachman, R., Nedd, A., \& Hinings, B. (1995). Analyzing cross-national management and organizations: A theoretical framework. In T. Jackson (Ed.), Cross-cultural management (n.p.). Oxford: Butterworth-Heinemann.

Lee, K., \& Carter, S. (2005). Global marketing challenges: Changes, challenges and new strategies. New York: Oxford University Press.

Linacre, J.M. (2011). WINSTEPS (Version 3.71.0) [Computer Software], Beaverton, OR Winsteps.com.

Mead, R. (1990). Cross-cultural management communication. Chichester: John Wiley

Moore, A., \& Bussin, M. (2012). Reward preferences for generations in selected Information and Communication Technology companies. SA Journal of Human Resource Management, 10(1), Art. \#325, 9 pages. http://dx.doi.org/10.4102/ sajhrm.v10i1.325

Munsamy, M., \& Venter, A. (2009). Retention factors of management staff in the maintenance phase of their careers in the local government. SA Journal of Human Resource Management, 7(1), Art. \#198, 9 pages. http://dx.doi.org/10.4102. v35i1.198

Newman, K., \& Nollen, S. (1996). Culture and congruence: The fit between management practices and national culture. Journal of International Busines Studies, 27(4), 753-779. http://dx.doi.org/10.1057/palgrave.jibs.8490152

Nicholls, M.L. (2012). The relationship between occupational culture, occupational groups and reward preferences. Doctoral Thesis. Johannesburg: University of Johannesburg.

Nienaber, R., \& Bussin, M. (2011). Remuneration policy and strategy. In M. Bussin (Ed.), The remuneration handbook for Africa: A practical and informative handbook for managing reward and recognition in Africa (n.p.). Johannesburg: Knowres Publishing.

Nienaber, R., Bussin, M., \& Henn, C. (2011). The relationship between personality types and Reward preferences. Acta Commercii, 11(2), Art. \#153, 9 pages.

Nye, C.D., \& Drasgow, F. (2011). Assessing goodness of fit: Simple rules of thumb simply do not work. Organizational Research Methods, 14(3), 548-570. http:// dx.doi.org/10.1177/1094428110368562

Nzukuma, K.C.C., \& Bussin, M. (2011). Job-hopping amongst African Black senio management in South Africa. SA Journal of Human Resource Management, 9(1), Art. \#360, 12 pages. http://dx.doi.org/10.4102/sajhrm.v9i1.360
O’Hara-Devereaux, M., \& Johansen, R. (1994). Globalwork: Bridging distance, culture and time. San-Francisco, CA: Jossey-Bass.

Pallant, J. (2007). SPSS survival manual: A step-by-step guide to data analysis using SPSS version 15 (3rd edn.). New York: Open University Press.

P-E Corporate Services SA (Pty) Ltd. (2010). Human resources practitioner's handbook. Johannesburg: P-E Corporate Services.

Punnett, B.J., \& Ricks, D.A. (1997). International business (2nd edn.). Cambridge: Blackwell Business.

Schein, E.H. (2004). Organizational culture and leadership (3rd edn.). San-Francisco, CA: Jossey-Bass.

Schlechter, A., Thompson, N., \& Bussin, M. (2015). Attractiveness of non-financial rewards for prospective knowledge workers. Employee Relations, 37(3), 274-295. http://dx.doi.org/10.1108/ER-06-2014-0077

Schuler, R., \& Rogocsky, N. (1998). Understanding compensation practice variations across firms: The impact of national culture. Journal of International Business Studies, 29(1), 159-177. http://dx.doi.org/10.1057/palgrave.jibs.8490030

Sheer, V.C. \& Chen, L. (2003). Successful Sino-western business negotiation: Participants' accounts of national and professional cultures. The Journal of Business Communications, 4O(1), 50-85. http://dx.doi.org/10.1177/002194360304000104

Shuck, M.B., Rocco, T.S., \& Albornoz, C.A. (2011). Exploring employee engagement from the employee perspective: Implications for HRD. Journal of European IndustrialTraining,35(4),300-325.http://dx.doi.org/10.1108/03090591111128306

Silverstone, Y. (2009). Preparing for the recovery: Five ways to get your organization ready now. Accenture. Retrieved July 14, 2015, from http://www.accenture.com/ Global/Research_and_Insights/By_Subject/Talent_and_Organization/Human Resources_Mgmt/Preparing-Recovery.htm

Smit, W., Stanz, K., \& Bussin, M. (2015). Retention preferences and the relationship between total rewards, perceived organisational support and perceived supervisor support. SA Journal of Human Resource Management, 13(1), Art. \#665, 13 pages. $h$ ttp://dx.doi.org/10.4102/sajhrm.v13i1.665

Snelgar, R.J., Renard, M., \& Venter, D. (2013). An empirical study of the reward preferences of South African employees. SA Journal of Human Resource
Management/SA Tydskrif vir Menslikehulpbronbestuur, 11(1), Art. \#351, 14 pages. Management/SA Tydskrif vir Menslikehulpbron
http://dx.doi.org/10.4102/sajhrm.v11i1.351

Thompson, P., \& McHugh, D. (2002). Work organisations: A critical introduction (3rd edn.). Basingstoke: Palgrave.

Trice, H.M. (1993). Occupational subcultures in the workplace. Ithaca, NY: ILR Press.

Trompenaars, F. (1993). Riding the waves of culture: Understanding cultural diversity in business. London: The Economist Books.

Ulijn, J., Nagel, A., \& Liang, T.W. (2001). The impact of national, corporate and professional cultures on innovation: German and Dutch firms compared. Journal of Enterprising Culture, 9(1), 21-52. http://dx.doi.org/10.1142/S0218495801000043/

Vandenberghe, C., St-Onge, S., \& Robineau, E. (2008). An analysis of the relation between personality and the attractiveness of total rewards components. Industrial Relations, 63(3), 425-453.

Viitanen, E. (2000). Characteristics of the occupational culture of physiotherapy in health centres. Advances in Physiotherapy, 2, 83-91. http://dx.doi.org/10.1080/ 140381900443346

Westerman, J.W., Beekun, R.I., Daly, J., \& Vanka, S. (2009). Personality and national culture: Predictors of compensation strategy preferences in the United States of America and India. Management Search News, 32(8), 767-781. http://dx.doi. org/10.1108/01409170910977988

WorldatWork. (2007). The WorldatWork handbook of compensation, benefits and total rewards: A comprehensive guide for HR professionals. Hoboken, NJ: John Wiley and Sons.

WorldatWork. (2008). WorldatWork total rewards model: Strategies to attract motivate and retain employees. Retrieved September 20, 2014, from http://www. worldatwork.org/pub/total rewards_model.pdf 